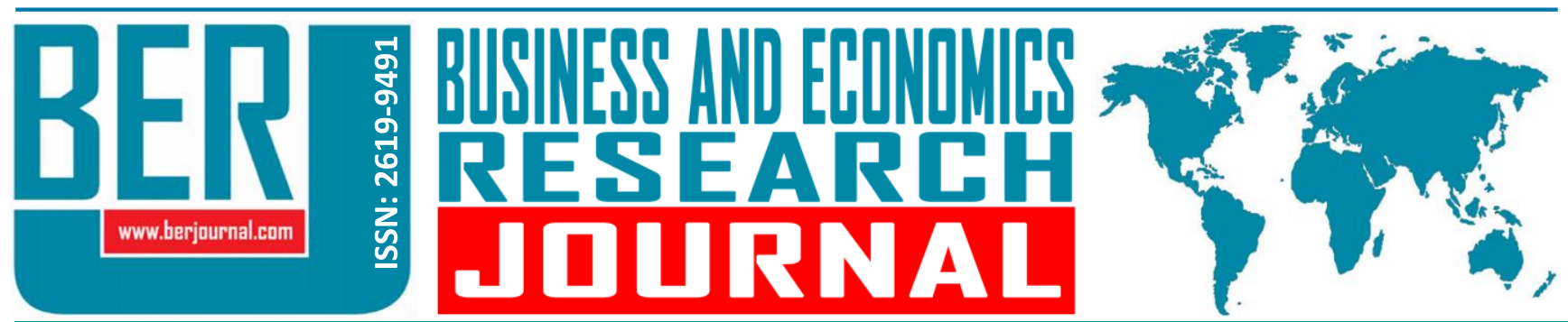

Business and Economics Research Journal Vol. 10, No. 1, 2019, pp. 259-276 doi: 10.20409/berj.2019.167

\section{Ürün Tercihlerini Etkileyen Ambalaj Tasarım Faktörlerinin Kısmi Yarar Konjoint Analizi İle Belirlenmesi: Organik Sabun Ürünü Üzerine Bir Çalışma*}

\begin{abstract}
Meltem Kiygi Calli ${ }^{\mathrm{a}}$, Semih Kilic ${ }^{\mathrm{b}}$
Öz: Bu çalışmanın amacı farklı ambalaj tasarımlarının tüketici satın alma niyetine olan etkilerini ortaya koymak ve bu etkinin hangi ambalaj tasarımı için en fazla olduğunu belirlemektir. Bu amaçla ambalaj tasarımında bulunan farklı faktörler belirlenmiş ve her faktörün tüketicinin satın alma niyetine olan etkisi incelenmiştir. Bu çalışmada ambalaj tasarımının faktörleri ambalajın şekli, rengi ve üzerindeki yazılar için kullanılan yazı stilidir. Tüketicinin satın alma niyetini en çok etkileyen ambalaj tasarım faktörünü belirlemek için bu araştırmada çevrimiçi anket yöntemi uygulanmış ve veriler toplanmıştır. Farklı ambalaj tasarımları görsel olarak tasarlanmış ve anket katılımcılarından farklı kombinasyonlardaki tasarımları satın alma niyetlerine göre derecelendirmeleri istenmiştir. Veriler kısmi yarar konjoint analiz yöntemi uygulanarak analiz edilmiştir. Sonuç olarak organik sabun ürünü için tüketici satın alma niyetine etki eden ve en yüksek önem değerine sahip ambalaj tasarımı belirlenmiştir. Analizle elde edilen fayda faktörünün katıımcıların demografik özelliklerine göre farklılı gösterip göstermediği incelenmiş, pazar bölümlendirme yöntemlerinden biri olan fayda temelli bölümlendirme ile elde edilen pazar bölümleri de bu çalıșmada araștırılmıștır.
\end{abstract}

\section{Determination of Packaging Design Factors Affecting Product Preferences by Part-Worth Conjoint Analysis: A Study on Organic Soap Products}

Abstract: The purpose of this study is to determine the effects of different packaging designs on consumer purchase intention and to determine the most effective packaging design. For this purpose, different factors in the packaging design are determined and the effect of each factor on the consumers' purchase intentions is investigated. In this study, the factors of the packaging design are the shape, color of the packaging and the writing style on it. In order to determine the most important factor of the packaging design, which affects the consumers' purchase intentions, online survey method is applied and data are collected. Different packaging designs are generated and the respondents are asked to rate the different design combinations according to their purchase intention. Data are analyzed by part-worth conjoint analysis method. As a result, the packaging design, which has an effect on consumers' preferences and purchase intentions and has the highest importance rate, has been determined for the organic soap product. It has been analyzed whether the benefit factor differs according to the demographic characteristics of the participants. Additionally, the market segments obtained by benefit-based segmentation, one of the market segmentation methods, are also investigated in this study.
Anahtar Sözcükler: Ambalaj Tasarımı, Satın Alma Niyeti, Konjoint Analizi, Kısmi Yarar, Fayda Temelli

Bölümlendirme

JEL: M30, M31, M39

$\begin{array}{ll}\text { Geliş } & : 23 \text { Ekim } 2018 \\ \text { Düzeltme } & : 19 \text { Aralık } 2018 \\ \text { Kabul } & : 28 \text { Aralık } 2018 \\ & \\ \text { Tür } & : \text { Araştırma }\end{array}$

Keywords: Package Design, Purchase Intention, Conjoint Analysis, Part-Worth, BenefitBased Segmentation

JEL: M30, M31, M39

Received : 23 October 2018

Revised : 19 December 2018

Accepted : 28 December 2018

Type : Research

a Asst. Prof., PhD., Kadir Has University, Faculty of Management, Department of Business Administration, Istanbul, Turkiye, meltem.kiygicalli@khas.edu.tr (ORCID: 0000-0002-2979-9309)

b PhD. Candidate, Yeditepe University, Graduate School of Social Sciences, Doctoral Program in Business Administration, Istanbul, Turkiye, semih.kilic@yahoo.com (ORCID: 0000-0002-6364-3607) 


\section{Giriş}

Tüm işletmeler hedef pazarların ihtiyaçlarını ve isteklerini karşılamak için kendi pazarlama stratejilerini geliştirmektelerdir. İşletmeler pazarlama stratejileri oluşturmayı ve pazarlama karması unsurlarını bir bütün olarak ele alarak müşteri memnuniyetini sağlamayı hedeflemektelerdir. Günümüzde tüketicilerin taleplerinde farklılıklar olması ve rekabetin artması sonucunda pazarda ürün çeşitliliği artmakta ve tüketicilerin ürün tercihlerinde farklılıklar gözlenmektedir. Teknolojinin gelişmesi ve ihtiyaçların farklılaşması ile birlikte ambalaj fonksiyonları da değişmektedir. Genel olarak ambalajın fonksiyonları koruyuculuk, kolaylık, fiyat ayarlama, görsellik, bilgi verme ve iletişimdir (Kocamanlar, 2009). Rundh (2005)'e göre ambalajın 10 farklı fonksiyonu koruma, muhafaza etme, dağııımı kolaylaştırma, müşteri tercihini teşvik etme, sattırma, bilgilendirme, tüketiciye kolaylık sağlama, fiyatlamaya yardımcı olma, hijyen ve güvenliği arttırma ve yenilikçiliktir.

Ambalaj ürünün somut bileşenlerinden biridir ve tüketicilerin satın alma niyetini etkileyen önemli bir unsurdur (Gofman, Moskowitz, Fyrbjork, Moskowitz ve Mets, 2009). Ambalaj bir ürünün tüketiciler tarafından daha kolay tanınmasını ve tüketicinin aklında kalmasını sağlamaktadır. Üründe ilk bakışta göze çarpan özellikler ambalajının stili, şekli, rengi ve ürünün fiyattır. Bu nedenle ambalaj tasarımı oldukça önemlidir. Bir ürüne tüketicilerin ilgisini çekmek için renklerin etkilerinden yararlanılmaktadır (Kocamanlar, 2009). Tüketicileri etkileyen renkler yardımıyla ürün ile tüketiciler arasında iletişim kurularak, ürünün hatırlanması ve ürünün tüketiciler tarafından satın alınması sağlanır. Ambalajlanan ürünün her yönüyle hedef pazarın ilgisini çekmesi ve tüketicinin gözünde iyi bir imaj oluşturması hedeflenir. Ambalajın görsel fonksiyonları tüketicinin satın alma niyetini etkilemektedir (Kocamanlar, 2009). Bu nedenle üreticiler tüketicileri etkileyecek görsel fonksiyonlardan oluşan ambalaj tasarımlarını araştırmakta ve bu araştırmalar sonucunda ürünlerinin ambalajlarına ve bu ambalajların görsel fonksiyonlarına karar vermektedirler.

Bu çalışmada farklı ambalaj tasarımlarının, tüketicilerin satın alma tercihlerindeki etkisi ve ambalaj faktörlerinden hangisinin tüketici satın alma niyetini en fazla etkilediği araştırımıştır. Tüketici tercihlerini etkileyecek ambalaj faktörleri şekil, renk ve yazı stili olarak ele alınmıştır. Bu amaçla anket yöntemi uygulanarak veri toplanmıştır. Elde edilen veriler konjoint analiz metodu ile analiz edilmiştir. Ayrıca farklı demografik özelliklere sahip tüketiciler ambalaj faktörlerinin önem seviyelerinin farklı olup olmadığı da araştııı ımıstır. Bu araştırmada, ambalajın çeşitli faktörlerinin faydaya olan nispi katkısını belirlemek için, konjoint analiz kullanılmıştır. Konjoint analizinin amacı, her bir özelliğin genel tercihlere ne kadar katkıda bulunduğunu belirlemektir (Cengiz, 2009). Bu katkının özelliği İngilizce'de "part-worth" olarak adlandırılır. Bu analizi kullanarak belirli müşteri veya pazar bölümleri için hangi özelliklerin önemli olduğunu belirlemek mümkündür. Değiştirilebilecek tüm özellikleri temsil eden hipotetik ürünler profil olarak adlandırılır. Bunlar tüketicilere gösterilir. Tüketicilerin, profili satın alma niyetlerine göre derecelendirmeleri istenir.

Bu çalışmaya konu olan ürün, kozmetik sektöründen sabun ürünüdür. Kozmetik sektöründe özellikle sabun ürünlerinin heterojen yapıya sahip bir tüketici kitlesi bulunmaktadır. Pazarda çok farklı özelliklerde sabun ürününün bulunması nedeniyle farklı ürünlerin hedef kitlesinin de farklı demografik özelliklerde olması beklenmektedir. Bu nedenle tüketicilerin farklı özellikleri göz önünde bulundurulduğunda tercihlerinin ve satın alma davranışlarının da farklılık göstereceği varsayılmaktadır. Organik ürünler ya da başka bir deyişle eko-ürünler günümüzde çok fazla popülerlik kazanmaktadır. Sosyal ve çevresel olarak sorumlu şirketler, organik olarak üretilen ürünleri ürün karmalarına alarak bu konuda bilinçli tüketiciyi ürünü satın almaya yönlendirmeyi amaçlarlar. Organik ürünlerin ambalajlarının çevre dostu olması gerekmeyebilir. Ancak, işletmelerin ürün karmasında organik ürünlere sahip olmak, bu şirketlerin kurumsal sosyal sorumluluk politikalarını yansıtabilir. Bu nedenle, tüketiciler organik ürünlerin kurumsal sosyal sorumluluk sürecinde üretildiğine inanabilirler (Pivato, Misani ve Tencati, 2008). Tüketicinin güveni de bu konuda çok önemlidir. Organik ürün endüstrisi, tüketicilerin organik ürünlere karşı davranışlarını, tercihlerini, algılarını ve tutumlarını daha iyi anlamalıdır. Literatürde ambalajın fonksiyonlarının genel olarak satın alma niyeti üzerindeki etkileri, ambalajın farklı özelliklerinin (görsel özellikler, fonksiyonel özellikler veya açıklayıcı bilgiler) satın alma niyeti üzerindeki etkisi veya satın alma niyetinde ambalajın etkisinin diğer etkenlere (fiyat, kalite, vb.) göre kaçıncı sırada olduğuna dair araştırmalar yapılmıştır (Sütütemiz, Çiftyıldız ve Konuk, 2009; Örücü ve Tavşancı, 2011; Gavcar ve Didin, 2012; Akpınar, Mevlüt, Oral, Akay ve Gülcan, 2015; Gök, Salkın, 
Kenanoğlu Bektaş ve Kınıklı, 2017). Literatürdeki araştırmalarda ürün olarak gıda ürünleri incelenmiştir. Bu araştırmada ambalaj etkenleri konjoint analizi ile incelenerek farklı kombinasyondaki (farklı renk, şekil ve yazı stili) ambalaj tasarımlarının tüketici tercihleri üzerindeki birleşik etkisi bulunmuştur. Etkenlerin birleşimlerinden elde edilen karma ambalaj tasarımının tüketici tercihleri üzerindeki etkisi araştırıldığında gerçek pazardaki ürünlerde de bu karma tasarım üzerinden tüketiciler tercih yaptıkları için araştırmanın gerçek hayattaki tüketici tercihlerini daha doğru yansıttığı öngörülmektedir. Gofman vd. (2009), bir gıda ürünü için farkıı bir yöntem kullanarak tüketici tercihi üzerinde en etkili ambalaj tasarımını araştırmışlardır. Fakat organik sabun ürününün ambalaj etkenlerinin tüketici tercihlerini nasıl etkilediği ve hangi ambalaj tasarımının tüketici tercihleri üzerinde en etkili olduğuna dair daha önce konjoint analizi ile yapılmış bir çalışma literatürde bulunmamaktadır. Bu çalışma ile literatürdeki bu boşluğa katkı sağlanarak araştırmacılara bir ana kaynak sunmak amaçlanmaktadır.

\section{Literatür Taraması}

\subsection{Ambalaj ve Fonksiyonları}

Ürün ambalajları ürünleri daha ilgi çekici hale getirmek ve ayırt edici özelliklerini vurgulamak için kullanılmaktadır. Bu nedenle ambalajın görsel fonksiyonlarının tüketici tercih ve satın alma niyetlerini etkileyecek düzeyde tasarlanması gerekmektedir. Örücü ve Tavşancı (2011) gıda ürünlerinde tüketicinin satın alma eğilimini etkileyen en önemli faktörleri anket uygulayarak araştırmışlar ve ambalajlamanın diğer faktörler arasında 5. sırada önemli olduğu ve ürünün şeklinin tüketici tercihinde etkili olduğu bulunmuşlardır. Bu çalışmaya ek olarak Gavcar ve Didin (2012) gıda sektöründe yaptıkları araştırmaya katılan kişilerin \%80'i tüketici tercihlerinde ambalajın önemli olduğunu belirtmişlerdir. Araştırmacılar üreticilerin kendi ürünlerinde uygulayabilecekleri farklı ürün kategorileri için tüketici tercih ve satın alma niyetlerini etkileyecek ambalaj tasarımlarının belirlenmesi amacıyla çeşitli çalışmalar yapmaktalardır. Gofman vd. (2009) gıda ürünü için tüketicilerin göz hareketlerini inceleyerek ambalaj etkenlerinden tüketici tercihini en çok etkileyen ambalaj tasarımını araştırmışlardır.

Ambalaj üzerindeki grafik tasarımı, yazı stili, baskısı, rengi ve ambalajın şekli, ambalajın görsel fonksiyonlarını oluşturur (Kocamanlar, 2009). Akpınar vd. (2015) araştırmalarında meyve suyu ürünü için yaptıkları ankette satın alma tercihini etkileyen en önemli faktörleri ambalajın rengi, biçimi ve ambalaj materyali olarak bulmuşlardır. Ürünün tüketici ile iletişimini sağlamada önemli etkenlerden biri ürünün grafik tasarımıdır. Grafik tasarımı çekici olan ürünler tüketicileri satın almaya sevk ederken, grafik tasarımı zayıf olan ürünler ise tüketicileri cezbetmez ve bu ürünler satın alınmaz. Farklı ambalajlar tüketicilerin ilgisini çekerken aynı zamanda grafik tasarım da ürünlerin akılda kalması açısından önemli etkiye sahiptir (Kocamanlar, 2009). Tüketicilerin satın alma davranışlarını etkileyen görsel unsurlardan bir diğeri ambalajın şeklidir. Ürünlerin farklı şekillerde ambalajları bulunmaktadır. Bunlar dikdörtgen, yuvarlak veya oval gibi şekillerde olabilmektedir (Kocamanlar, 2009). Sütütemiz vd. (2009) ambalaj özelliklerinin tüketicilerce dikkate alınan ve önemsenen ürün özellikleri olduğunu söylemişlerdir. Ayrıca ambalajın büyüklüğü ve ambalaj materyalinin ürün tercihinde önemli etkileri olduğunu araştırmalarında bulmuşlardır. Ürün ambalajlarının kendine özgü bir yazı stili ve rengi bulunmaktadır. Ambalaj üzerindeki yazı stili ve rengi, markanın imajının ve algısının oluşumunda etkilidir. Bu sebepten dolayı, ambalaj üzerindeki bu özellikler markanın doğru konumlandırılmasında bir role sahiptir (Benlioğlu, 2007). Eğlenceli bir marka imajını çağrıştıran yazı tipleri normalden daha yuvarlak yazı tipine sahipken, kontrollü bir marka el yazısı şeklindeki yazı stili ile kendini ifade edebilir (Sünnetçioğlu, 2006). Büyük harf, zıt renkler ve resim içeren etiketlere sahip ambalajlı ürünlerin marka adı ve ambalajla ilgili bilgileri içeren yazısı müşteri tarafından rahat bir şekilde görüleceği için, bu ürünler satış noktalarında alt raflarda yer alsa dahi tüketicilerin dikkatini çekecektir (Sünnetçioğlu, 2006). Ambalaj üzerindeki baskının tüketicilerin normal algılama mesafesinde okunabilir ve marka imajına uygun olması gerekmektedir. Raflarda bulunan ürünlerin baskı elemanlarının yaklaşık 1 metre uzaklıktan görülebilmesi gerekmektedir. Üzerinde bu tarzda baskı bulunan ambalajlar daha kolay algılandığından tüketicilerin satın alma eğilimine etkisi bulunmaktadır (Kocamanlar, 2009). 
Ambalaj ve ürün renkleri ürünlerin akılda kalıcılığı açısından önem taşımaktadır. Gök vd. (2017) çalışmalarında tüketicilerin eğitim ve gelir seviyesi yükseldikçe ambalaj rengi, görünüş ve tasarımını daha çok göz önünde bulundurdukları sonucuna varmışlardır. Renkler, tüketici ile iletişim kurma, onları ikna etme, ürüne olan ilgiyi arttırma ve duyguları yansıtmada kullanılabilir. Ambalaj üzerindeki renkler, tüketicileri psikolojik açıdan ve satın alma niyetleri açısından etkiler (Çakıcı, 1987). Özdemir (2005) renklerin psikolojik etkileri ve yansıttığı duyguları araştırmıştır. Bu araştırma sonucuna göre sarı renk, hareketli, neşeli ve parlak bir imaj çizerken bolluğu, zenginliği ve sadakati temsil etmektedir. Buna ek olarak, solgun bir sarı insanı dinlendiren bir özelliğe sahipken canlı sarı bunun tam tersi olarak insanı harekete geçirir. Beyaz renk ise masumiyetin, saflığın, temizliğin ve birliğin sembolü olarak görülmüştür. Siyah renk, yas, pişmanlık ve suçluluk gibi kavramları çağrıştııırken aynı zamanda dinlendirici, sessizlik, sonsuzluk ve yapısal kuvveti temsil edebilir. Yeşil renk, doğanın rengi, serinletici ve sakinleştirici olarak algılanmaktadır. Mavi renk ise dürüstlüğü, merhameti, uzlaşmayı, huzuru ve iyi niyeti yansıtmaktadır. Son olarak kırmızı rengin heyecan verici, dinamik, dikkat arttırıı ve ilgiyi çeken bir yapısı vardır. Fakat kırmızı renk abartılmış bir şekilde kullanılırsa tehlikeli, agresif ve güçlü gibi anlamları ifade edebilir.

\subsection{Tüketici Satın Alma Niyeti}

Tüketicinin bir ürün veya hizmeti satın alma isteğine ya da eğilimine satın alma niyeti adı verilir (Çağlın, 2015). Satın alma kararı ile satın alma niyeti birbirinden ayrı kavramlar olup, birbiri ile bütünleşiklerdir (Odabaşı ve Barış, 2003). Satın alma niyetinin oluşması aşamasında tüketiciler uyaranlara karşı oldukça duyarı davranmaktadır. Satın alma niyetini arttıran belirli etkenler satın alma zamanının belirlenmesi, alınacak ürün miktarlarının netleştirilmesi ve marka ve/veya ürün seçiminin yapılması olarak verilebilir.

Ambalaj tüketicilerin satın alma kararını almasını etkileyen faktörlerden biridir. Günümüzde artan rekabet ve ürün benzerliklerinden dolayı işletmeler tüketicilerin satın alma kararını etkileyen unsurları (örneğin; ürün ambalajı) iletişim aracı olarak kullanıp kendi ürünlerini diğer işletmelerin markalarından ayırt edici hale getirmektedir (Koyuncu, 2007). Ambalaj bir pazarlama aracı haline gelmiştir. Bu sebepten dolayı, asında pazarlama karması içerisinde ürün başlı̆ı altında ele alınan ambalaj son zamanlarda artan önemi sayesinde pazarlamanın beşinci P'si olarak adlandırılmaktadır (Kotler ve Keller, 2012).

Tüketicinin ürünü satın alıp almama kararına yönlendiren etmen o ürünün sahip olduğu ambalajdır. Bu karar aşamasında ambalaj üzerindeki marka görseli, fiziksel ve grafiksel tasarımlar tüketiciyi yönlendirir (Göbel, 2008). Günümüzde, ambalaj tasarımları ve değişiklikleri tüketicilerin istekleri ve zevkleri doğrultusunda yapılmaktadır (Çelen-Özcan, 2014). Özellikle, plansız olarak gerçekleştirilen alışverişlerde ürün ambalajının ürün seçiminde en önemli unsur olduğu gözlenmiştir (Koyuncu, 2007).

\section{Metot ve Veri}

$\mathrm{Bu}$ çalışmanın amacı, ambalaj tasarım faktörlerinden farklı ambalaj rengi, şekli ve ambalajın üzerindeki farklı yazı stilinin tüketicilerin satın alma niyetine olan etkilerinin araştııılmasıdır. Farklı ambalaj faktörlerinden oluşan karma ambalaj tasarımının tüketici satın alma niyetine olan etkileri değişmektedir. Yapılan literatür araştırmasında elde edilen sonuçlar neticesinde bu araştırmada ürün tercihinde etkili olan faktörler ambalajın rengi, şekli ve yazı stili olarak belirlenmiştir. Araştırma yapılan ambalaj tasarımı için kozmetik sektöründen organik sabun ürünü seçilmiştir. Bu araştırmada belirlenen ürün için ambalaj rengi, şekli ve yazı stili faktörlerinden hangisinin tüketiciler için daha yüksek fayda değeri yarattığı belirlenmiştir. Ayrıca, çalışma sonucunda elde edilen ambalaj faktörlerinin önem değerlerinin tüketicilerin demografik özelliklerine göre değişkenlik gösterip göstermediği de araştırılmıştır. Böylece fayda temelli bölümlendirmede tüketicilerin demografik özellikleri kullanılarak pazar bölümlendirme yapılıp yapılmayacağı da analiz edilmiştir (Ceylan, 2013).

Her bir faktörün satın alma niyetine olan nispi etkisini bütün faktörlerinin karmasından oluşan bir ambalaj üzerinden ayrı ayrı belirlemek mümkün olamamaktadır. Bu nedenle bu çalışmada belirlenen her bir ambalaj faktörünün satın alma niyetine nispi etkisinin elde edilebileceği kısmi yarar konjoint analizi yöntemi uygulanmıştır. Konjoint analizi, bir ürün veya hizmete karşı tüketicilerin tepkilerini anlamak için kullanılan bir 
yöntemdir (Çemrek, 2001). Örneğin yeni ürün geliştirmede nihai ürünü belirlemek için veya bir ürün veya servis için optimum fiyatı belirlemek için oluşturulan anket ile tüketicilerin tercih ve satın alma niyeti veri olarak toplandıktan sonra konjoint analizi uygulanarak bu durumlardaki en etkili ve doğru kararların alınması sağlanabilir. (Tuncalı, 2007). Konjoint analizi, özellikleri kesin olarak bilinen değişkenlerin etkilerini belirlemek için geliştirilmiştir. Analizde tüketicilerin tercihlerini etkileyebilecek faktörler ve bu faktörlerin düzeyleri belirlenir (Cengiz, 2009). Örneğin bu faktörler, ambalajın şekli ve rengi gibi faktörler olabilmektedir. Bu faktörlerin düzeyleri belirlenirken faktörler detaylandııılır. Örneğin renk faktörünün düzeyleri, mavi, kırmızı, yeşil, sarı gibi renkler olabilmektedir. Faktörler ve düzeyleri belirlendikten sonra bunların kombinasyonundan oluşan bir anket oluşturulur ve bu anket katılımcılara sunulur ve bu kombinasyonları satın alma niyetine göre derecelendirmeleri istenir. Konjoint analizi ile en çok tercih edilen veya tüketicilerin satın alma niyetine en çok etki eden ambalaj tasarım faktörlerinin nispi etkisi belirlenerek en çok faydayı yaratan faktör belirlenir ayrıca belirlenen ambalaj tasarım faktörlerinin hepsi için tek tek en etkili düzeyleri elde edilir. Böylece en çok tercih edilen veya tüketicilerin satın alma niyetine en çok etki eden ambalaj tasarımı kombinasyonu bulunur. Ambalaj faktörlerinin fayda değerleri aşağıda verilen fayda formülünden hesaplanır. Her bir değişken için fayda değeri bu fayda formülü ile belirlenir. Formülde geçen $\beta_{1}, \beta_{2}$ ve $\beta_{3}$ değerleri, değişken düzeyleri ile değişkenin tercih edilmesi arasındaki ilişkiyi gösteren kat sayılardır.

Fayda $=\beta_{0}+\beta_{1} X_{\text {renk }}+\beta_{2} X_{\text {şekil }}+\beta_{3} X_{\text {font }}$

Daha önce yapılan çalışmalar göstermektedir ki ürün veya hizmete ait faydaların önem seviyelerinin belirlenmesinde genellikle faktör analizi kullanılmaktadır (Ceylan, 2013). Bu yöntemde ürün veya hizmetin faydasına ilişkin çok sayıda maddenin katılımcı tarafından ayrı ayrı değerlendirilmesi istenmektedir. Bir sonraki aşama olan kümeleme analizinin verisini ise faktör analizi sonucu elde edilen faktör skorları oluşturmaktadır. Neredeyse bütün tüketiciler, ürün ve hizmetlerden mümkün olduğunca en fazla faydayı elde etmek istemektedir ama ürün ve hizmetlerin faydalarına yönelttikleri göreceli önemler farklılıklar göstermektedir. Bu sebeple, faktör analizi ile yapılan çalışmada katılımcı her bir soruyu diğer maddelerden soyut olarak değerlendireceği için çoğu zaman ilgili faydaya gerçekte olduğundan daha fazla değer atfetme eğilimindedir; ki bu da çalışmayı gerçeklikten ve güvenirlikten uzaklaştırmaktadır. Bu nedenle bu çalışmada faktör analizi metodundan farklı olarak konjoint analizi metodu kullanılmıştır (Ceylan, 2013).

Konjoint analizi yönteminde en önemli aşama değişkenlerin belirlenmesi ve anket formunun hazırlanması sırasında izlenecek yolun seçimidir. Anket formunun oluşturulmasında üç farklı yöntem vardır (Aydın ve Yalçın, 2016). Birinci yöntem, her seferinde iki değişkenin göz önüne alındığı trade-off yöntemi (two factor at a time trade-off); ikinci yöntem, tüm değişkenlerin birlikte değerlendirildiği tam kavram yöntemi (full-concept) ve üçüncü yöntem ise diğer iki yöntemin birleşimi biçiminde ortaya çıkan bileşen ya da ikili karşılaştırma (pairwise comparison) yöntemidir (Green ve Srinivasan, 1978). Bu araştırmada tam kavram yöntemi kullanılmıştır çünkü diğer iki yöntemde benzer kombinasyonlar birçok kez katılımcıların önüne konulacağı için ve bu kombinasyonların önem sırasına dizilmesinde zorluklar bulunduğu için tam kavram yöntemi tercih edilmiştir.

Konjoint analizinde kullanılmak için öncelikle tüketici satın alma niyetini etkileyecek tüm faktörler ve bu faktörlere bağıı düzeyler belirlenmiştir. Basitleştirilmiş organik sabun ambalajı tasarımı için üç farklı faktör seçilmiştir. Bu faktörler, ambalaj rengi, ambalaj şekli ve ambalaj üzerindeki yazı stilidir.

Bu çalışma sırasında ön araştırma yapılarak ve organik ürünlerde en çok kullanılan ambalaj renkleri incelenerek renk faktörü için düzeyler belirlenmiştir. Birinci faktör olan renk için beyaz, mavi, yeşil ve turuncu olmak üzere dört farklı düzey seçilmiştir. Renk üzerine yapılan araştırmalar literatürde taranmış olup Özdemir'de (2005) anlatıldığı gibi renklerin psikolojik etkileri ve yansıttığı duygular incelenerek yeşil rengi doğayı temsil ettiği için; beyaz rengi saflığı temsil ettiği için; mavi rengi huzuru temsil ettiği ve insanın kendini iyi hissetmesini sağladığı için; turuncu rengi ise neşe ve mutluluk verici anlam taşıdığı, diğer renklere göre zıt bir renk olduğu için, ayrıca sabun markalarının son zamanlarda bu rengi sabun ambalajlarında sıkça kullandığı için tercih edilmiştir (Jones, 2014; Cosmeticosbr, 2015). íkinci faktör olan ambalaj şekli için yuvarlak ve dikdörtgen olarak iki düzey belirlenmiştir. Genellikle sabun ambalajları dikdörtgen veya yuvarlak şekilde olduğu için şekil faktörü bu belirtilen iki düzeyde oluşturulmuştur. Üçüncü faktör olan ambalajın üzerindeki 
yazı stili için ise düz yazı ve el yazısı olmak üzere iki düzey belirlenmiştir. Şekil 1'de ambalaj tasarımı faktörlerine ilişkin bilgiler görsel olarak yer almaktadır. Buna göre oluşturulan ambalaj tasarımının renk, şekil ve yazı stili görülmektedir. Dikdörtgen ve yuvarlak ambalajlar için farklı renkler, renklerin tonlamaları ve ambalajın üzerinde yazan '\%100 Organik Sabun' yazısının düz yazı ve el yazısı ile yazılmış tasarımı bulunmaktadır.

\section{Şekil 1. Sabun için Ambalaj Tasarımı Faktörleri}

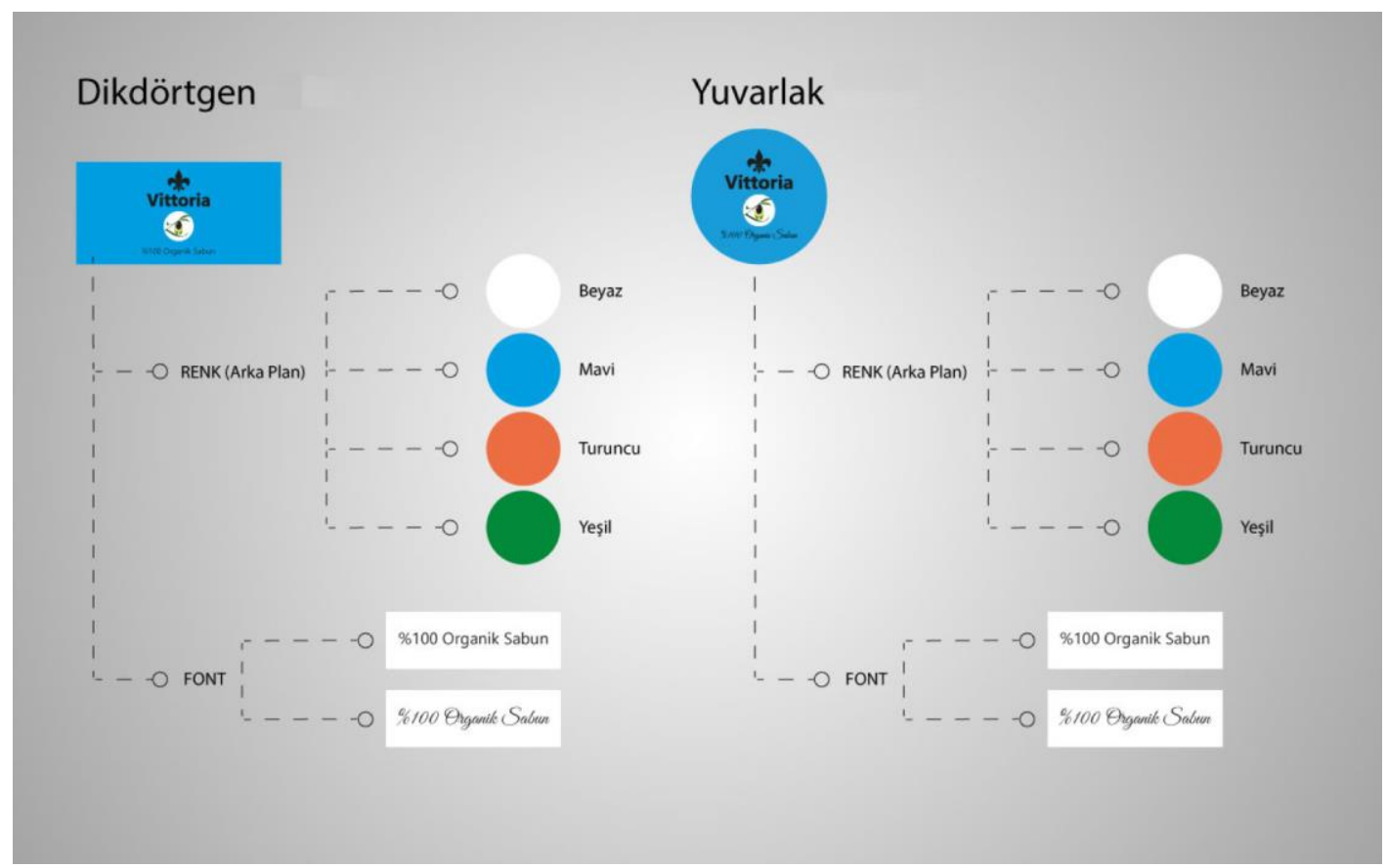

Tablo 1'de belirlenen faktörler ve faktörlerin düzeylerinin açıklaması bulunmaktadır. Renk, şekil ve yazı stili olmak üzere üç faktör bulunmaktadır. Renk faktörü dört düzeye sahiptir. Bunlar; yeşil, beyaz, mavi ve turuncudur. Şekil değişkeninde iki düzey vardır. Bunlar; dikdörtgen ve yuvarlaktır. Yazı stili değişkeninde ise iki düzey vardır. Bunlar; düz yazı ve el yazısıdır. Modeldeki ilişki düzeyi, sayısal olarak belirtilen verilerden oluşmadığı için kategorik olarak belirtilmiştir. Bu araştırmada, ambalaj tasarımının tüketici tercihlerine ve satın alma niyetine olan etkileri belirlenmiştir.

Tablo 1. Ambalaj Tasarım Faktörlerinin Açıklamaları

\begin{tabular}{ccccc}
\hline Faktör & $\begin{array}{c}\text { Düzey } \\
\text { Sayısı }\end{array}$ & Açıklamalar & ilişsi Düzeyi & $\begin{array}{c}\text { Kategorik } \\
\text { Değerler }\end{array}$ \\
\hline Renk & 4 & Yeşil, Beyaz, Mavi, Turuncu & Kategorik & $1,2,3,4$ \\
Şekil & 2 & Dikdörtgen, Yuvarlak & Kategorik & 1,2 \\
Yazı Stili & 2 & Düz Yazı, El Yazısı & Kategorik & 1,2 \\
\hline
\end{tabular}

Araştırma hipotezleri, organik sabun ambalajı için belirlenen faktörlere ve katılımcıların demografik özelliklerine bağlı olarak tüketici satın alma niyetinin değişim gösterip göstermediğine göre aşağıda verilen şekilde belirlenmiştir. Bu çalışmada belirlenen hipotezler:

(a) Organik sabun ürünü için ambalajın rengi tüketicinin satın alma niyetine etki eden faktörlerden fayda değeri en yüksek olan faktördür;

(b) Organik sabun ürünü için tüketicinin satın alma niyetine etki eden faktörlerden ambalajın şeklinin fayda değeri yazı stilinin fayda değerine göre daha yüksektir; 
(c) Organik sabun ürünü için mavi renk ambalaj tüketicinin satın alma niyetine etki eden faktörlerden fayda değeri en yüksek olan ambalaj rengidir;

(d) Organik sabun ürünü için ambalajın üzerinde yer alan el yazısı şeklindeki yazı stili tüketicinin satın alma niyetine etki eden faktörlerden fayda değeri en yüksek olan yazı stilidir;

(e) Organik sabun ürünü için yuvarlak ambalaj şekli tüketicinin satın alma niyetine etki eden faktörlerden fayda değeri en yüksek olan ambalaj şeklidir;

(f) Organik sabun ürünü için ambalajın rengine tüketicilerin verdikleri önem cinsiyete göre farklılıklar gösterir;

(g) Organik sabun ürünü için ambalaj rengine tüketicilerin verdikleri önem eğitim düzeyine göre farklılıklar gösterir;

(h) Organik sabun ürünü için ambalaj rengine tüketicilerin verdikleri önem gelir seviyesine göre farklılıklar gösterir;

(ı) Organik sabun ürünü için ambalaj şekline tüketicilerin verdikleri önem yaşa göre farklılıklar gösterir;

(i) Organik sabun ürünü için ambalaj şekline tüketicilerin verdikleri önem medeni duruma göre farklılıklar gösterir.

Faktör düzeyleri bir araya getirildiğinde toplamda $4 * 2 * 2=16$ adet farklı ambalaj tasarımı kombinasyonu oluşmaktadır. Fakat bütün kombinasyonlarla organik sabun ambalajı oluşturulup katılımcıların bu ambalaj tasarımlarını değerlendirmesi zor olacağı için IBM SPSS istatistiksel veri analizi programında ortogonal bir düzen oluşturularak bu 16 farklı ambalaj tasarımı sekiz farklı deneysel dizayn kombinasyonuna indirilmiştir. Deneysel dizayn tasarımları ortogonal dizayndan çıkan ve tüketicilere değerlendirmesi için sunulan tasarımlardır. Dizayn tasarım kombinasyonları Tablo 2'de listelenmektedir. Örneğin birinci tasarımın ambalaj rengi mavi, ambalaj şekli dikdörtgen ve ambalaj üzerindeki yazı stili düz yazı stili olacaktır.

Tablo 2. Ortogonal Düzen Tasarımları

\begin{tabular}{cccl}
\hline Renk & Şekil & Yazı Stili & Statü \\
\hline Mavi & Dikdörtgen & Düz Yazı & Dizayn \\
Turuncu & Yuvarlak & Düz Yazı & Dizayn \\
Yeşil & Dikdörtgen & Düz Yazı & Dizayn \\
Yeşil & Yuvarlak & El Yazısı & Dizayn \\
Turuncu & Dikdörtgen & El Yazısı & Dizayn \\
Mavi & Yuvarlak & El Yazısı & Dizayn \\
Beyaz & Yuvarlak & Düz Yazı & Dizayn \\
Beyaz & Dikdörtgen & El Yazısı & Dizayn \\
\hline
\end{tabular}

Bu tasarım kombinasyonlarına ek olarak dört tane de gizli tasarım kombinasyonu seçilmiştir. Gizli tasarımlar, ortogonal düzenden çıkan ve tüketicilere değerlendirmesi için sunulan fakat sadece konjoint analizin geçerliliğini test etmek için kullandığımız tasarımlardır. Gizli tasarımlar, ortogonal dizayn yöntemi ile seçilmeyip, dizayn dışında kalan ve seçilmesi mümkün olan kombinasyonlar arasından tesadüfi olarak seçilmektedir (Özçiçek-Dölekoğlu, 2002). 
Tablo 3. Gizli Tasarımlar Listesi

\begin{tabular}{cccc}
\hline Beyaz & Dikdörtgen & Düz Yazı & Gizli \\
Turuncu & Yuvarlak & El Yazısı & Gizli \\
Beyaz & Yuvarlak & El Yazısı & Gizli \\
Yeşil & Yuvarlak & Düz Yazı & Gizli \\
\hline
\end{tabular}

Dizayn ve gizli tasarımlar için toplamda 12 farklı organik sabun ambalaj tasarımı için anket oluşturulmuştur. Böylelikle Tablo 2 ve 3'de gösterilen tasarım kombinasyonları tüketicilere sunulacak anket için tasarlanmış ve bu tasarımları katılımcıların satın alma niyetlerine göre 1'den 9'a kadar derecelendirmeleri istenmiştir. Ayrıca ankette bulunmayan ama analiz yapılırken kullanılan simülasyon tasarımları vardır. Simülasyon tasarımları, farklı faktör ve düzeyler için oluşturulan bütün kombinasyonlarda dizayn ve gizli tasarımların kombinasyonlarından arta kalan bütün tasarımlardır. Bu tasarımlar katıımcılara değerlendirmesi için sunulmayıp sadece konjoint analizinin sonuçlarına göre fayda puanlarının hesaplanması için kullanılmaktadır (Şen ve Çemrek, 2004). Simülasyon tasarımları optimum faydayı sağlayacak kombinasyonun belirlenmesinde diğer tasarımlar ile birlikte değerlendirilmektedir. Tablo 4'de simülasyon tasarım kombinasyonları listelenmiştir.

Tablo 4. Simülasyon Tasarımları Listesi

\begin{tabular}{cccc}
\hline Yeşil & Dikdörtgen & El Yazısı & Simülasyon \\
Mavi & Dikdörtgen & El Yazısı & Simülasyon \\
Mavi & Yuvarlak & Düz Yazı & Simülasyon \\
Turuncu & Dikdörtgen & Düz Yazı & Simülasyon \\
\hline
\end{tabular}

Bu çalışmada veri analizi için gereken bütün istatistiksel işlemler IBM SPSS 22.0 istatistiksel analiz programı ile yapılmıştır. Ambalaj tasarımının tüketici satın alma niyetine olan etkisini ölçmek için kullandığımız ankette bulunan faktörlerin güvenirliğini Cronbach's Alpha değeri hesaplanarak analiz edilmiştir. Ankette cevaplayıcılara sunulan 12 tasarım için Cronbach's Alpha değeri 0,913 olarak bulunmuştur. Bu sonuç oluşturulan anketin yüksek derecede güvenilir olduğunu göstermektedir. Bu çalışma sonucunda konjoint analiz metodu uygulanarak her bir faktörün fayda değeri ve önem yüzdesi elde edilmiştir. Her bir katılımcı için her etkenin önem yüzdesi bu fayda değerleri kullanılarak hesaplanmıştır. Pazar bölümlendirme yöntemlerinden biri olan fayda temelli bölümlendirme yapılabilmesi için bu anket katılımcılarının demografik özellikleri kullanılarak fayda temelli bölümlendirme yapılıp nasıl bölümler elde edilebileceği araştırılmıştır. Fayda temelli bölümlendirme için anket katılımcılarının vermiş oldukları önem yüzdeleri ve demografik faktörlerden cinsiyet ve medeni durum için T-testi; yaş, eğitim seviyesi ve gelir düzeyi için ANOVA analizi gerçekleştirilmiştir.

Araştırma sabun satın alan tüketiciler üzerinde gerçekleştirilmiştir. Araştırmanın evreni İstanbul'da yaşayan 15 yaşını doldurmuş müşterilerdir. Ergenlik dönemi ile birlikte bireylerin kozmetik ürün satın almaya ve ebeveynlerinden bağımsız kendi kendine satın almaya karar vermeye başlamaları sebebiyle 15 yaş ve üzeri araştırma evreni olarak belirlenmiştir. Veri toplamak amacıyla internette anket oluşturulmuş ve yayınlanmıştır. Bu araştırmanın zaman ve maliyet açısından tesadüfi olmayan örnekleme yöntemlerinden kolayda örnekleme yönetimi seçilmiştir. Çevrimiçi anket 5 Mayıs 2016 ile 20 Mayıs 2016 tarihleri arasında yayınlanmıştır. Derecelendirme ölçekleri, ölçülen niteliğin kategorik değil, sürekli bir değişken olduğunu kabul eder (Köklü, 1995). Bu yüzden N sonsuza giderken \%5 anlamlılık düzeyinde 120 kişinin üzerinde olan bir örneklem sayısı bu çalışmanın yapılabilmesi için yeterli olacaktır (Özdemir, 2010). 15 günlük süre sonunda çevrimiçi olarak toplanan 209 adet anket formu elde edilmiştir. Örneklem büyüklüğü 120 kişiden büyük olduğu için örneklem büyüklüğü araştırma için uygundur. Araştırmanın örneklemi çeşitli yaş, gelir durumu, eğitim durumu, medeni durum ve farklı cinsiyete sahip 209 adet sabun tüketicisinden oluşmaktadır. 
Araştırmada kullanılan anket formu iki bölümden oluşmaktadır. Anket formunun birinci bölümünde organik sabun ambalajı tasarımlarının tüketici satın alma niyetine olan etkilerini belirlemeye yönelik $9^{\prime} l u$ derecelendirme ölçeği kullanılarak 12 soru oluşturulmuştur (Gofman vd., 2009). Dizayn ve gizli tasarımlar olmak üzere toplam 12 farklı sabun ambalajı tasarımının tüketicilerin satın alma ihtimali 9'lu derecelendirme ölçeği kullanılarak ölçülmüştür. Derecelendirme ölçeğindeki değerlendirme kriterleri: 1: en düşük, ..., 9: en yüksek şekildedir. Aşağıda örnek bir anket sorusu verilmektedir. Literatürde genellikle konjoint analizi araştırmalarında kombinasyonlar bir kart üzerine yazılarak anket katılımcılarının bu kartları en çok tercih edilenden en az tercih edilene doğru sıralamaları veya bu kart üzerinde yazılan özelliklerden oluşan kombinasyonları satın alma niyetine göre derecelendirmeleri istenir (Sönmez, 2006; Saraçlı ve Şıklar, 2005). Bu araştırmada bunlardan farklı olarak kombinasyonların hipotetik görselleri oluşturulmuş ve katılımcıların bu görsel tasarımları satın alma niyetlerine göre derecelendirmeleri istenmiştir.

Şekil 2. Anket Soru Örneği (Beyaz Renk, Yuvarlak Şekil, El Yazısı Kombinasyonu)

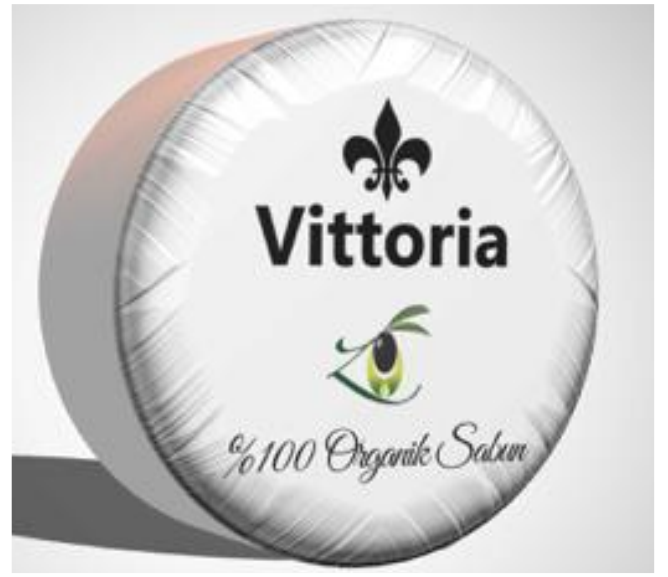

Yukarıdaki ürünü satın alma ihtimalinizi derecelendiriniz.

1: En Düşük, 9: En Yüksek

$\begin{array}{lllllllll}1 & 2 & 3 & 4 & 5 & 6 & 7 & 8 & 9\end{array}$

Anketin ikinci bölümünde ise, tüketicilerin demografik özelliklerine yönelik sorular bulunmaktadır. Bunlar, yaş için "15-20 yaş arası, 21-30 yaş arası, 31-45 yaş arası, 46-59 yaş arası, 60 yaş ve üzeri" seçilmiştir. Türkiye'de nüfus genç denilebilecek bir nitelik taşımaktadır. Ortalama olarak 0-14 yaş grubu nüfusun \%35'ini, $15-64$ yaş grubu nüfusun $\% 60,7$ 'sini, 65 ve üzeri yaş grubu ise nüfusun \%4,3'ünü oluşturmaktadır. Ergenlik dönemi ile birlikte bireylerin kozmetik ürün satın almaya ve kendi kendine satın almaya karar vermeye başlamaları sebebiyle 15 yaş, demografik özellik sorularındaki yaş başlangıç seviyesi olarak belirlenmiştir (Penpece, 2006). Cinsiyet için; "Kadın, Erkek”, eğitim durumu için; “ilkokul, Lise, Ön lisans, Lisans, Lisansüstü”, medeni durum için; "Evli, Bekar", gelir seviyesi için; "0-1500 TL, 1500-3000 TL, 3000-4500 TL, 4500 TL ve üzeri" seçenekleri yer almaktadır.

\section{Bulgular}

Anket katılımcılarının \%58,9'u erkek, \%41,1'i kadınlardan oluşmaktadır. Katılımcıların yaş dağılımına bakıldığında \%9,6'sı 15-20 yaş aralığında, \%64,1'i 21-30 yaş aralığında, \%20,1'i 31-45 yaş aralığında \%4,8'i 4659 yaş aralığında olup \%1,4'ü 60 yaş ve üzeridir. Katılımcıların eğitim düzeyi ise \%0,5'i ilköğretim, \%9,1'i lise, \%9,1'i ön lisans, \%62,2'si lisans ve \%19,1'i lisansüstü seviyesindedir. Katılımcıların \%64,1'i bekar, \%35,9'u evlidir. Anket katılımcılarının \%31,6'sı 0-1500 TL, \%28,7'si 1500-3000 TL, \%20,6'sı 3000-4500 TL, \%19,1'i 4500 TL ve üzeri gelir düzeyindedir. 

Üzerine Bir Çalışma

Konjoint analizi anket sonuçları kullanılarak tüketicilerin satın alma niyetini etkileyen ambalaj tasarım faktörlerin her birinin fayda değerlerini bulmak amacıyla uygulanmıştır. Bu analiz sonuçlarına göre organik sabun ambalajı tasarımındaki farklı faktör ve düzeylerin tahmini fayda değerleri bulunmuştur. Bu değerler Tablo 3'de gösterilmektedir. Fayda değer tablosundaki fayda tahminlerine göre en yüksek faydayı renk faktörü için beyaz $(0,449)$, şekil faktörü için yuvarlak $(0,117)$, yazı stili faktörü için ise el yazısı $(0,055)$ düzeyleri sağlamaktadır.

Tablo 3. Fayda Değer Tablosu

\begin{tabular}{|l|c|c|c|}
\hline \multicolumn{2}{|c|}{} & Fayda Tahmini & Standart Hata \\
\hline \multirow{4}{*}{ Renk } & Yeşil & 0,103 & 0,149 \\
\cline { 2 - 4 } & Beyaz & 0,449 & 0,149 \\
\cline { 2 - 4 } & Mavi & $-0,215$ & 0,149 \\
\cline { 2 - 4 } & Turuncu & $-0,337$ & 0,149 \\
\hline \multirow{2}{*}{ Şekil } & Dikdörtgen & $-0,117$ & 0,086 \\
\cline { 2 - 4 } & Yuvarlak & 0,117 & 0,086 \\
\hline \multirow{2}{*}{ Yazı Stili } & Düz Yazı & $-0,055$ & 0,086 \\
\cline { 2 - 4 } & El Yazısı & 0,055 & 0,086 \\
\hline \multicolumn{2}{|c|}{$\beta_{0}$ (Sabit Değer) } & 5,212 & 0,086 \\
\hline
\end{tabular}

Tablo 4 konjoint analizi sonuçlarına göre ankete katılan tüketicilerin ambalaj tasarımı tercihlerinde en çok önem verdikleri faktörleri sıralamaktadır. Renk faktörü diğer iki faktöre kıyasla en önemli faktördür. Renk faktörünün önem oranı \%56,718'dir. İkinci önemli değişken ise şekil faktörüdür. Şekil faktörünün diğer faktörler arasındaki önem oranı \%27,417'dir. En az önem düzeyine sahip faktör ise yazı stili faktörüdür. Yazı stili faktörünün diğer faktörler arasındaki önem oranı \%14,823'tür.

Tablo 4. Önem Değerleri Tablosu (Ortalama Önem Değerleri)

\begin{tabular}{|l|l|}
\hline Renk & 56,718 \\
\hline Şekil & 27,417 \\
\hline Yazı Stili & 14,823 \\
\hline
\end{tabular}

Tablo 5'de belirtilen Pearson's $\mathrm{R}$ ve Kendall's Tau değerlerine göre, kurulan model anket katılımcılarının tercihlerine uygundur. Pearson's R değerine bakıldığında kurulan model ile gözlenen sonuçlar arasında \%93,9'luk anlamlı bir ilişki bulunmaktadır. Gizli tasarımlar için Kendall's tau değerine bakıldığında ise oluşturulan modelin tüketicilerin tercihlerine uygun olduğu sonucuna varılmaktadır (Gizli Tasarımlar için Kendall's tau=1).

Tablo 5. Korelasyon Tablosu

\begin{tabular}{|l|c|c|}
\hline & Değer & Anlamlılık Düzeyi \\
\hline Pearson's R & 0,939 & 0,000 \\
\hline Kendall's tau & 0,929 & 0,001 \\
\hline Kendall's tau (Gizli Tasarımlar) & 1,000 & 0,021 \\
\hline
\end{tabular}

Tablo 6'da dizayn ve gizli tasarımların IBM SPSS İstatistiksel Analiz Programı'nda yapılan konjoint analiz sonuçlarına göre farklı kombinasyonlu organik sabun ambalajı tasarımlarının fayda değerleri gösterilmiştir. Tabloya göre dizayn ve gizli tasarımların arasında en çok tercih edilen özelliklere ve düzeylere sahip tasarım 5,833 fayda oranıyla beyaz, yuvarlak ve el yazısı kombinasyonlarından oluşan ankette tüketicilere sunulan 11 numaralı tasarımdır. 
Tablo 6. Sabun Ambalajı Fayda Oranları

\begin{tabular}{|c|c|c|c|c|c|}
\hline Tasarım & Renk & Şekil & Yazı Stili & Statü & Fayda Oranı \\
\hline Tasarım 1 & Mavi & Dikdörtgen & Düz Yazı & Dizayn & 4,826 \\
\hline Tasarım 2 & Turuncu & Yuvarlak & Düz Yazı & Dizayn & 4,938 \\
\hline Tasarım 3 & Yeşil & Dikdörtgen & Düz Yazı & Dizayn & 5,143 \\
\hline Tasarım 4 & Yeşil & Yuvarlak & El Yazısı & Dizayn & 5,487 \\
\hline Tasarım 5 & Turuncu & Dikdörtgen & El Yazısı & Dizayn & 4,813 \\
\hline Tasarım 6 & Mavi & Yuvarlak & El Yazısı & Dizayn & 5,169 \\
\hline Tasarım 7 & Beyaz & Yuvarlak & Düz Yazı & Dizayn & 5,724 \\
\hline Tasarım 8 & Beyaz & Dikdörtgen & El Yazısı & Dizayn & 5,599 \\
\hline Tasarım 9 & Beyaz & Dikdörtgen & Düz Yazı & Gizli & 5,490 \\
\hline Tasarım 10 & Turuncu & Yuvarlak & El Yazısı & Gizli & 5,047 \\
\hline Tasarım 11 & Beyaz & Yuvarlak & EI Yazısı & Gizli & 5,833 \\
\hline Tasarım 12 & Yeşil & Yuvarlak & Düz Yazı & Gizli & 5,378 \\
\hline
\end{tabular}

Konjoint analizi sonucunda oluşturulan renk, şekil ve yazı stili için fayda değerleri aşağıdaki şekilde yer almaktadır. Şekil 3-5'de sunulan fayda grafiklerinden çıkardığımız sonuç doğrultusunda en yüksek faydayı beyaz renk, en az faydayı turuncu renk sağlamaktadır. Şekil olarak en yüksek faydayı yuvarlak şekil sağlarken, en az faydayı dikdörtgen şekli sağlamaktadır. Yazı stili fayda grafiğinden çıkardığımız sonuç doğrultusunda en yüksek faydayı el yazısı yazı stili, en az faydayı ise düz yazı stili sağlamaktadır.

Şekil 3. Renk Fayda Grafiği

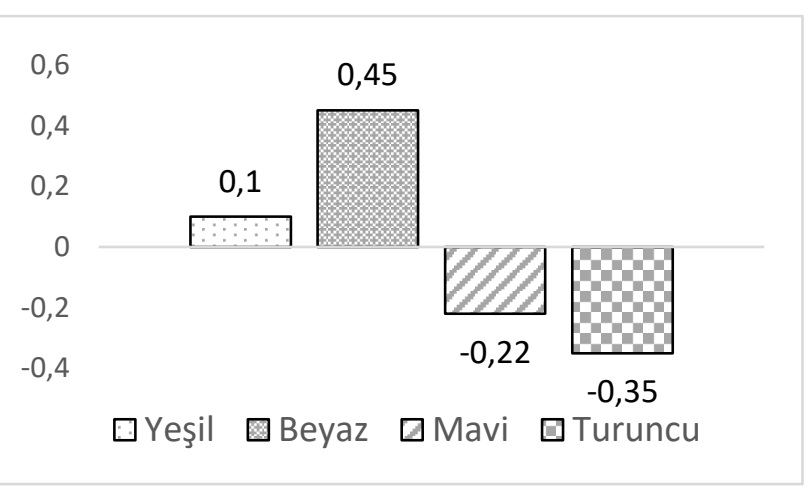

Şekil 4. Şekil Fayda Grafiği

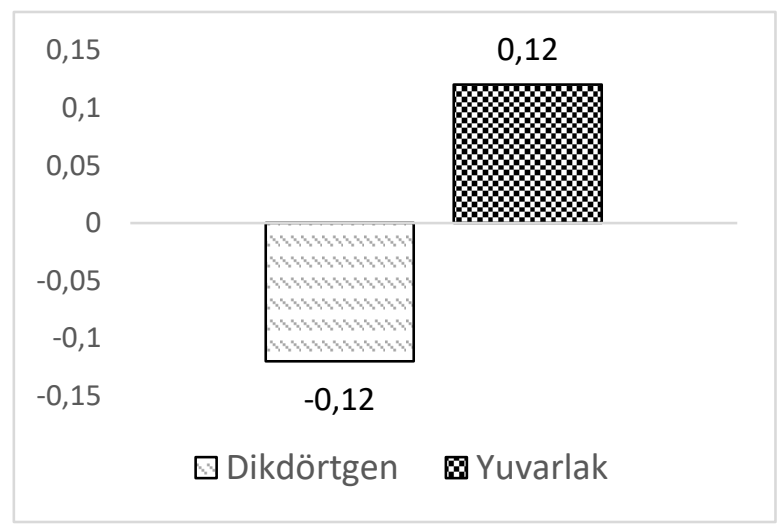


Şekil 5. Yazı Stili Fayda Grafiği

\begin{tabular}{|c|c|c|}
\hline 1 & & 0,52 \\
\hline 0,5 & & | \\
\hline$-0,5$ & \multicolumn{2}{|c|}{ \$1/, 1} \\
\hline-1 & $-0,52$ & \\
\hline & × Düz Yazı & ' El Yazısı \\
\hline
\end{tabular}

Şekil 6' da değişkenlerin fayda grafiği verilmiştir. Renk faktörü organik sabun ambalajı tercihlerine etki eden ve en yüksek faydayı sağlayan değişkendir. Şekil faktörü, renk faktörüne göre daha az fayda sağlarken en az faydayı yazı stili faktörüne sağlamaktadır.

Şekil 6. Faktörlerin Önem Düzey Grafikleri

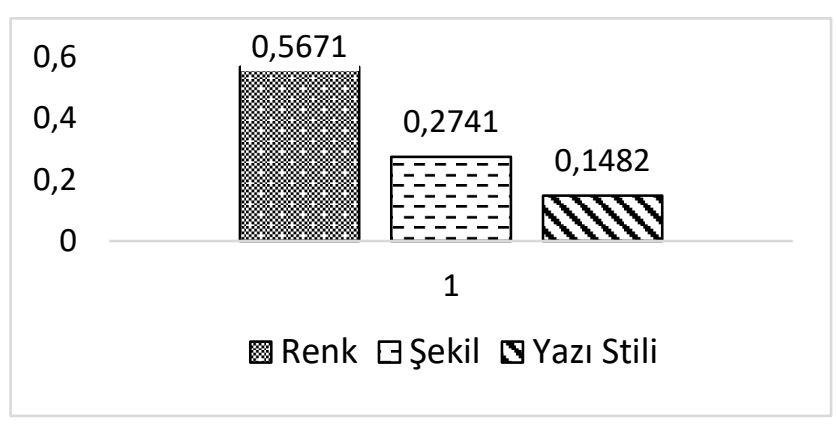

Tablo 7'de belirtilen ve simülasyon için hazırlanmış tasarımlar anket katılımcılarına sunulmamış olup sadece simülasyon tasarımlarının fayda oranlarının hesaplanması için kullanılmıştır. Tablo 7 incelendiğinde en çok tercih edilen özelliklere sahip simülasyon tasarımı 5,253 fayda oranıyla Tasarım 1 olduğu görülmektedir. İkinci en yüksek fayda oranına sahip simülasyon tasarımı 5,060 fayda oranıyla Tasarım 3, üçüncü en yüksek fayda oranına sahip simülasyon tasarımı 4,935 fayda oranıyla Tasarım 2, en düşük fayda oranına sahip simülasyon tasarımı ise 4,703 fayda oranıyla Tasarım 4 olmuştur. Böylece simülasyon tasarımlarından en yüksek fayda oranına sahip olan kombinasyon yeşil renkli, dikdörtgen şeklinde ve el yazısı ile üzerindeki yazılar yazıımış organik sabun ambalajıdır.

Tablo 7. Sabun Ambalajı Fayda Oranları - Simülasyon

\begin{tabular}{|c|c|c|c|c|c|}
\hline Tasarım & Renk & Şekil & Yazı stili & Statü & Fayda oranı \\
\hline Tasarım 1 & Yeşil & Dikdörtgen & El yazısı & Simülasyon & 5,253 \\
\hline Tasarım 2 & Mavi & Dikdörtgen & El yazısı & Simülasyon & 4,935 \\
\hline Tasarım 3 & Mavi & Yuvarlak & Düz Yazı & Simülasyon & 5,060 \\
\hline Tasarım 4 & Turuncu & Dikdörtgen & Düz Yazı & Simülasyon & 4,703 \\
\hline
\end{tabular}


Simülasyon tasarımlarına ait verilerden çıkartılacak sonuçlar ileride pazara sürülecek ürünlerin test edilmesi ya da pazara yeni giriş aşamasında olan ürünler için fikir vermesi amacıyla kullanılabilir (Turanlı, Cengiz ve Işık, 2013). Tablo 8'de simülasyon tasarımları için maksimum fayda değerlerine bakıldığında \%37,1'lik fayda oranıyla 1. sabun (Tasarım 1) ambalajının en yüksek pazar payına sahip olacağı görülmektedir. İkinci sırada \%35,1'lik maksimum fayda oranıyla 3. sabun (Tasarım 3) ambalajı yer almaktadır. Üçüncü sırada ise $\% 15,8^{\prime}$ lik maksimum fayda oranıyla 2. sabun (Tasarım 2) ambalajı bulunmaktadır. En düşük pazar payına sahip sabun ambalajı ise \%11,9'luk maksimum fayda oranıyla 4. sabundur.

Tablo 8. Simülasyonların Tercih Olasılıkları

\begin{tabular}{|c|c|c|c|c|}
\hline Tasarım & ID & Maksimum Fayda & Bradley-Terry-Luce & Logit \\
\hline 1 & 13 & $\% 37,1$ & $\% 26,8$ & $\% 30,9$ \\
\hline 2 & 14 & $\% 15,8$ & $\% 24,4$ & $\% 21,3$ \\
\hline 3 & 15 & $\% 35,1$ & $\% 25,4$ & $\% 29,5$ \\
\hline 4 & 16 & $\% 11,9$ & $\% 23,5$ & $\% 18,3$ \\
\hline
\end{tabular}

Araştırmaya ek olarak pazar bölümlendirme yöntemlerinden biri olan fayda temelli bölümlendirme yapılabilmesi için ankete katılan kişiler için önem değerleri tek tek hesaplanmıştır. Önem değerleri her bir faktör için maksimum fayda değeri ile minimum fayda değerinin farkının her bir faktör için bu fayda değeri aralığının toplamına bölünerek hesaplanmıştır. Elde edilen değerler her bir faktör için önem yüzde değerlerini vermektedir (Karaduman ve Yılmaz, 2015). Bu değerlerin anket katılımcılarının demografik özelliklere göre değişip değişmediği t-testi ve varyans analizi (ANOVA) ile test edilmiştir (Ceylan, 2013). Testlerin sonuç tabloları Tablo 9-Tablo 13'te verilmektedir.

Tablo 9 cinsiyete göre t-testi sonuçlarını vermektedir. Bu tabloya göre, renk önem düzeyinin anket katılımcılarının cinsiyet faktörüne göre değişip değişmediğine bakıldığında, varyansların eşitliği Levene Testi sonuçlarına göre $(p=0,131>0,05)$ varyansların homojen dağıldığı sonucuna varılmış ve cinsiyete göre renk öneminin farklı olduğu hipotezi \%5 anlamlılık düzeyinde red edilmiştir $(p=0,623>0,05)$. Bu sonuca göre renk faktörü önem düzeyi cinsiyete göre farklılık göstermemektedir. Şekil önem değerinin anket katılımcılarının cinsiyetine göre farklılık gösterip göstermediği de t-testi ile analiz edilmiştir. Bu testin sonuçlarına göre \%5 anlamlılık düzeyinde varyansların homojen dağıldığı görülmektedir $(p=0,096>0,05)$ ve şekil öneminin cinsiyete göre farklı olduğu hipotezi \%5 anlamlılık düzeyinde red edilir ( $p=0,081>0,05)$. Bu sonuca göre şekil faktörü önem düzeyi cinsiyete göre farklılık göstermemektedir. Yazı stili önem değeri anket katılımcılarının cinsiyetine göre farklıık gösterip göstermediği yine t-testi ile analiz edilmiştir. Bu testin sonuçlarına göre \%5 anlamlılık düzeyinde varyansların homojen dağıldığı görülmektedir $(p=0,906>0,05)$ ve yazı stili öneminin cinsiyete göre farklı olduğu hipotezi $\% 5$ anlamlılık düzeyinde red edilir $(p=0,059>0,05)$. Bu sonuca göre yazı stili faktörü önem düzeyi cinsiyete göre farklılık göstermemektedir.

Tablo 9. T-Testi Sonuçları - Cinsiyet

\begin{tabular}{|c|c|c|c|c|c|c|}
\hline \multirow[b]{2}{*}{ Faktörler } & & \multicolumn{2}{|c|}{$\begin{array}{c}\text { Varyansların Eşitliği } \\
\text { Levene Testi }\end{array}$} & \multicolumn{3}{|c|}{$\begin{array}{c}\text { Ortalamaların Eşitliği } \\
\text { T-Testi }\end{array}$} \\
\hline & & $\mathbf{F}$ & Sig. & $t$ & dF & Sig. (2-tailed) \\
\hline \multirow[t]{2}{*}{ Renk Önem Değeri } & Kab.ed. eşit var. & 2,29 & 0,131 & $-0,49$ & 188 & 0,623 \\
\hline & Kab. olmayan eşit var. & & & $-0,5$ & 178 & 0,614 \\
\hline \multirow[t]{2}{*}{ Şekil Önem Değeri } & Kabul ed. eşit var. & 2,79 & 0,096 & 1,75 & 188 & 0,081 \\
\hline & Kab. olmayan eşit var & & & 1,81 & 181 & 0,071 \\
\hline \multirow[t]{2}{*}{ Yazı Stili Önem Değeri } & Kabul ed. eşit var. & 0,014 & 0,906 & $-1,9$ & 188 & 0,059 \\
\hline & Kab. olmayan eşit var & & & $-1,89$ & 164 & 0,06 \\
\hline
\end{tabular}


Tablo 10 medeni duruma göre t-testi sonuçlarını vermektedir. Bu tabloya göre, renk önem düzeyinin anket katılımcılarının medeni durumlarına göre değişip değişmediğine bakıldığında, $t$-test sonucuna göre olduğu için varyansların homojen dağıldığı görülmektedir $(p=0,306>0,05)$. Medeni duruma göre renk öneminin farklı olduğu hipotezi $\% 5$ anlamlılık düzeyinde red edilir $(p=0,85>0,05)$. Bu sonuca göre renk faktörü önem düzeyi medeni duruma göre farklııı göstermemektedir. Şekil önem değerinin anket katılımcılarının medeni durumlarına göre farklılık gösterip göstermediği de t-testi ile analiz edilmiştir. Bu testin sonuçlarına göre $\% 5$ anlamlııık düzeyinde varyansların homojen dağıldığı görülmektedir $(p=0,94>0,05)$ ve şekil öneminin medeni duruma göre farklı olduğu hipotezi $\% 5$ anlamlılık düzeyinde red edilir $(p=0,879>0,05)$. Bu sonuca göre şekil faktörü önem düzeyi medeni duruma göre farklılık göstermemektedir. Yazı stili önem değeri anket katılımcılarının medeni durumuna göre farklılık gösterip göstermediği yine t-testi ile analiz edilmiştir. Bu testin sonuçlarına göre $\% 5$ anlamlılık düzeyinde varyansların homojen dağıldığı görülmektedir $(p=0,222>0,05)$ ve yazı stili öneminin medeni duruma göre farklı olduğu hipotezi $\% 5$ anlamlılık düzeyinde red edilir $(p=0,943>0,05)$. Bu sonuca göre yazı stili faktörü önem düzeyi medeni duruma göre farklılık göstermemektedir.

Tablo 10. T-Testi Sonuçları - Medeni Durum

\begin{tabular}{|l|l|c|c|c|c|c|}
\hline \multirow{2}{*}{ Faktörler } & & \multicolumn{2}{|c|}{$\begin{array}{c}\text { Varyansların Eşitliği } \\
\text { Levene Testi }\end{array}$} & \multicolumn{3}{|c|}{$\begin{array}{c}\text { Ortalamaların Eşitliği } \\
\text { T-Testi }\end{array}$} \\
\cline { 3 - 7 } & & $\mathbf{F}$ & Sig. & $\mathbf{t}$ & $\mathbf{d F}$ & Sig. (2-tailed) \\
\hline Renk Önem Değeri & Kab.ed. eşit var. & 1,05 & 0,306 & $-0,18$ & 188 & 0,85 \\
& Kab. olmayan eşit var. & & & $-0,18$ & 111 & 0,856 \\
\hline \multirow{2}{*}{ Şekil Önem Değeri } & Kabul ed. eşit var. & 0,006 & 0,94 & 0,15 & 188 & 0,879 \\
& Kab. olmayan eşit var & & & 0,15 & 123 & 0,879 \\
\hline Yazı Stili Önem Değeri & Kabul ed. eşit var. & 1,5 & 0,222 & 0,07 & 188 & 0,943 \\
& Kab. olmayan eşit var & & & 0,06 & 105 & 0,947 \\
\hline
\end{tabular}

Tablo 11 yaş değişkenine göre ANOVA testi sonuçlarını vermektedir. Renk faktörü tüketicilerin yaşlarına göre anlamlı bir farklılık göstermez $(p=0,35>0,05)$. Şekil önem değeri için \%95 güven düzeyinde yapılan $F$ testi sonucuna göre şekil faktörü tüketicilerin yaşlarına göre anlamlı farklılık göstermez $(p=0,311>0,05)$. Yazı stili önem değeri için $\% 95$ güven düzeyinde yapılan $F$ testi sonucuna göre yazı stili faktörü tüketicilerin yaşlarına göre anlamlı bir farklılık göstermez $(p=0,658>0,05)$.

Tablo 11. ANOVA Testi Sonuçları - Yaş

\begin{tabular}{|l|l|c|c|}
\hline \multirow{2}{*}{ Faktörler } & & \multicolumn{2}{|c|}{ ANOVA Testi } \\
\cline { 3 - 4 } & & F & Sig. \\
\hline Renk Önem Değeri & Gruplar Arası & 1,128 & 0,345 \\
\hline Şekil Önem Değeri & Gruplar Arası & 1,203 & 0,311 \\
\hline Yazı Stili Önem Değeri & Gruplar Arası & 0,608 & 0,658 \\
\hline
\end{tabular}

Tablo 12 ve Tablo 13'de eğitim durumu ve aylık gelir için ANOVA test sonuçları verilmektedir. Tablo 12 'de verilen sonuçlara göre renk, şekil ve yazı stili önem değerleri için $\% 95$ güven düzeyinde yapılan $\mathrm{F}$ testi sonucuna göre bu faktörler tüketicilerin eğitim düzeyine göre anlamlı farklılıklar göstermezler. Tablo $13^{\prime}$ de verilen sonuçlara göre renk, şekil ve yazı stili önem değerleri için \%95 güven düzeyinde yapılan $F$ testi sonucuna göre bu faktörlerin tüketicilerin aylık gelirine göre de anlamlı farklılıklar göstermediği sonucuna ulaşıımıştır. 
Tablo 12. ANOVA Testi Sonuçları - Eğitim Durumu

\begin{tabular}{|l|l|c|c|}
\hline \multirow{2}{*}{ Faktörler } & & \multicolumn{2}{|c|}{ ANOVA Testi } \\
\cline { 3 - 4 } & & F & Sig. \\
\hline Renk Önem Değeri & Gruplar Arası & 1,846 & 0,122 \\
\hline Şekil Önem Değeri & Gruplar Arası & 1,848 & 0,121 \\
\hline Yazı Stili Önem Değeri & Gruplar Arası & 0,894 & 0,469 \\
\hline
\end{tabular}

Tablo 13. ANOVA Testi Sonuçları - Aylık Gelir

\begin{tabular}{|l|l|c|c|}
\hline \multirow{2}{*}{ Faktörler } & & \multicolumn{2}{|c|}{ ANOVA Testi } \\
\cline { 3 - 4 } & & F & Sig. \\
\hline Renk Önem Değeri & Gruplar Arası & 1,113 & 0,345 \\
\hline Şekil Önem Değeri & Gruplar Arası & 1,162 & 0,326 \\
\hline Yazı Stili Önem Değeri & Gruplar Arası & 0,46 & 0,711 \\
\hline
\end{tabular}

Bu çalışmadan elde edilen sonuçlara göre bu araştırmanın hipotezlerinden (a), (b), (d) ve (e) hipotezleri \%5 anlamlılık düzeyinde kabul edilmiştir. Buna göre kabul edilen hipotezler aşağıda listelenmektedir.

(a) Organik sabun ürünü için ambalajın rengi tüketicinin satın alma niyetine etki eden faktörlerden fayda değeri en yüksek olan faktördür;

(b) Organik sabun ürünü için tüketicinin satın alma niyetine etki eden faktörlerden ambalajın şeklinin fayda değeri yazı stilinin fayda değerine göre daha yüksektir;

(d) Organik sabun ürünü için ambalajın üzerinde yer alan el yazısı şeklindeki yazı stili tüketicinin satın alma niyetine etki eden faktörlerden fayda değeri en yüksek olan yazı stilidir;

(e) Organik sabun ürünü için yuvarlak ambalaj şekli tüketicinin satın alma niyetine etki eden faktörlerden fayda değeri en yüksek olan ambalaj şeklidir.

\section{Sonuc}

Bu araştırma kapsamında organik sabun ambalajı için tüketici satın alma niyetini etkileyen faktör ve düzeyler belirlenmiştir. Hangi faktör ve bu faktör düzeylerinin sağladığı fayda değerinin yüksek olduğu ve bu faktörlerden en yüksek önem seviyesine sahip olan faktör 209 kişilik bir örneklem ile araştırılmıştır. Araştırma için kısmi yarar konjoint analizi metodundan yararlanılmış ve analizler IBM SPSS İstatistiksel Analiz Programı ile yapılmıştır.

Literatürde bu çalışma öncesinde organik sabun ürünü ambalaj faktörlerinin en yüksek faydaya sahip olan etkenlerin belirlendiği ve tüketici satın alma niyetini en çok etkileyen ambalaj tasarımının araştırıldığı bir çalışma yer almamaktadır. Bu nedenle bu çalışma literatürdeki bu boşluğu dolduran bu konuda yapılmış ilk çalışmadır. Bu araştırmada organik sabun ambalaj faktörleri olarak renk, şekil ve yazı stili belirlenmiş olup bu faktörlerin farklı düzeyleri için de en yüksek faydaya sahip olan etkenler belirlenmiştir. Bu sonuçlara göre en yüksek önem değerine sahip faktör renk olarak bulunmuştur. Fayda değeri en yüksek olan düzeyler ise; beyaz renk, yuvarlak şekil ve el yazısıdır. Bu sonuçlar doğrultusunda ve Türk kültüründe beyaz rengin saflığı ve temizliği temsil ettiği düşünüldüğünde organik bir ürün için satın alma niyetini en çok etkileyen ve en yüksek fayda değerine sahip renk olması doğal bir sonuç olarak değerlendirilmiştir. Organik ürünler için pazarda en çok tercih edilen renklerin yeşil ve mavi olmasına rağmen beyaza oranla daha az fayda sağladığı analiz sonuçlarından görülmektedir. Bu çalışma örneklemi Türkiye'den seçilmiş olup uluslararası düzeyde değerlendirilecek olursa renk, şekil ve yazı stili faktörleri ve bu faktörlerin düzeyleri için tüketici tercihleri kültürel farklıııklara göre değişkenlik gösterebileceği göz önünde bulundurulmalıdır. 
Sonuç olarak, tüketicilerin demografik özellikleri değerlendirildiğinde; yaş, cinsiyet, eğitim durumu, medeni durum ve gelir seviyesi farklılıkları, tüketicilerin organik sabun ürünü ambalajı üzerinde renk, şekil ve yazı stili faktörlerine belirgin bir önem değeri vermelerini değiştirmediği gözlenmiş olup satın alma niyetini etkilemediği gözlemlenmiştir. Bu nedenle araştırmada bahsedilen fayda temelli pazar bölümlendirmenin bu demografik değişkenlere göre yapılması birbirinden çok farklı pazar bölümleri elde edilmesini sağlamayacağı için bu çalışmada bu bölümlendirme türünün kullanılmaması önerilmektedir. Bunun yerine coğrafik bölümlendirme veya psikografik bölümlendirme yapılması uygun olabilir. Bu tür bölümlendirmelerin uygulanması bu çalışmada araştırılmamış olup ileriki çalışmalarda bu tür bölümlendirmeler analiz edilip araştırma genişletilebilir.

Gelecek araştırmalarda, araştırmacıların yapacakları çalışma kozmetik sektöründe organik sabun ürünü üzerine olacaksa renk faktör düzeylerini arttırarak, fiyat ve ağırlık gibi farklı faktörleri de araştırmaya dahil etmeleri önerilmektedir. Örneğin; çalışmaya eklenecek olan yeni faktörlerden hangilerinin tüketiciyi etkilediği, fiyat değişkenine bağlı olarak ilgili ürüne tüketicilerin en çok ne kadar para ödeyebilecekleri gibi konular da araştırılabilir.

Bu çalışmada faktörler için tüketicilerin verdiği önem yüzdeleri ve faktör düzeyleri için fayda oranları hesaplanmıştır. Gelecek araştırmalarda bilimsel yaklaşımlar kullanılarak tüketicilerin faktör ve düzey tercihlerinin altında yatan nedenler de incelenebilir.

Yapılan çalışmanın sonuçlarına göre organik sabun üreticilerinin ya da bu pazara yeni girecek girişimcilerin satın alma niyetini daha fazla etkileyen beyaz rengi ürünlerinin ambalaj rengi olarak kullanmaları genel olarak önerilmektedir. Ayrıca organik sabun üreticilerine yuvarlak şekilli sabunların üretimini daha fazla yapmaları ve pazara sunmaları bu çalışmadaki fayda ve önem sonuçlarına göre önerilmektedir. Yazı stili olarak el yazısının ürün ambalajı üzerinde kullanılması tüketici satın alma niyetini daha fazla pozitif yönde etkilediği sonucuna da bu çalışmada ulaşılmıştır.

\section{Son Notlar}

* Bu çalışma; Dr. Öğretim Üyesi Meltem Kıygı Çallı’nın danışmanlı̆ı̆nda, Semih Kılıç tarafından yazılan "Ambalaj Tasarımının Tüketici Tercihi ve Satın Alma Niyetine Olan Etkisi: Organik Sabun Ambalajı Üzerine Bir Uygulama" isimli Yüksek Lisans Tezinden türetilmiştir. Yüksek Lisans Tezi kabul tarihi: 24.06.2016 Istanbul Okan Üniversitesi.

\section{Kaynaklar}

Akpınar, M. G., Mevlüt, G. Ü. L., Oral, M. A., Akay, A. Ş., \& Gülcan, S. (2015). Meyve suyu ürünleri satın alma tercihinde ambalaj faktörünün değerlendirilmesi. Dumlupınar Üniversitesi Sosyal Bilimler Dergisi, 44, 58-67.

Aydın, N., \& Yalçın, E. (2016). Seçime dayalı konjoint analizi ve bir uygulama. Dumlupınar Üniversitesi Sosyal Bilimler Dergisi, 50, 26-48.

Benlioğlu, N. (2007). Sabun ambalajlarında tasarım sorunları ve dalan sabunları için bir uygulama. Hacettepe Üniversitesi Sosyal Bilimler Enstitüsü, Yüksek Lisans Tezi, Ankara.

Cengiz, E. (2009). Tüketicilerin ürün tercihinde rol oynayan ürün menşeinin, marka, fiyat ve kalite değişkenleri açısından incelenmesi. Atatürk Üniversitesi Iktisadi ve Idari Bilimler Dergisi, 23(2), 155-174.

Ceylan, H. H. (2013). Perakende sektöründe konjoint ve kümeleme analizi ile fayda temelli pazar bölümlendirme. Celal Bayar Üniversitesi İktisadi ve Idari Bilimler Fakültesi Yönetim ve Ekonomi Dergisi, 20(1), 143-154.

Cosmeticosbr, (2015). L'Occitane en provence launces solidarity soap in Brazil. http://www.cosmeticosbr.com.br/conteudo/en/loccitane-en-provence-lanca-sabonete-solidario-no-brasil/ (Erişim tarihi, 22 Ekim 2018).

Çağlın, C. (2015). Raf yönetiminin satın alma niyetine etkisi: Inndirim marketlerinde bir araştırma. Niğde Üniversitesi Sosyal Bilimler Enstitüsü, Yüksek Lisans Tezi, Niğde.

Çakıcı, L. (1987). İşletmelerde ambalaj sorunları ve ambalajlama alanındaki gelişmeler (2.Baskı). Ankara: A.Ü. Siyasal Bilgiler Fakültesi Yayınları No. 559. 
Çelen-Özcan, S. (2014). Ürün ambalajının tüketicinin satın alma kararına etkisi. Karabük Üniversitesi Sosyal Bilimler Enstitüsü, Yüksek Lisans Tezi, Karabük.

Çemrek, F. (2001). Tüketici tercihlerinin belirlenmesinde kullanılan konjoint analizi ve kredi kartı tipi tercihlerine ilişkin bir uygulama. Osmangazi Üniversitesi Fen Bilimleri Enstitüsü, Yüksek Lisans Tezi, Eskişehir.

Gavcar, E., \& Didin, S. (2012). Tüketicilerin “perakendeci markalı” ürünleri satın alma kararlarını etkileyen faktörler: Muğla il merkezi'nde bir araştırma. Uluslararası Yönetim iktisat ve işletme Dergisi, 3(6), 21-32.

Gofman, A., Moskowitz H. R., Fyrbjork, J., Moskowitz, D., \& Mets, T. (2009). Extending rule developing experimentation to perception of food packages with eye tracking. The Open Food Science Journal, 3, 66-78.

Gök, B., Salkın, M., Kenanoğlu Bektaş, Z., \& Kınıklı, F. (2017). Tüketicilerin süt ve süt ürünleri satın alma tercihinde ambalajın etkisi: İzmir ili örneği. Turkish Journal of Agricultural Economics, 23(2), 241-253.

Green, P. E., \& Srinavasan, V. (1978). Conjoint analysis in consumer research: Issues and Outlook. Journal of Consumer Research, 5, 103-123.

Göbel, Ü. (2008). Tüketicilerin satın alma kararında ambalajın etkisi ve bir uygulama. Abant İzzet Baysal Üniversitesi Sosyal Bilimler Enstitüsü, Yüksek Lisans Tezi, Bolu.

Jones, E. (2014). L'occitane's solidarity soap launches in support of world sight day. https://www.getthegloss.com/news/l-occitane-s-solidarity-soap-goes-on-sale-in-support-of-world-sightday?eu_cookie_banner_read=1 (Erişim tarihi, 22 Ekim 2018).

Karaduman, I.., \& Yılmaz, N. K. (2015). Rezidans dairesi satışında müşteri tercihlerini etkileyen faktörler ve pazar payı analizinde konjoint yönteminin kullanımı. Giresun Üniversitesi İktisadi ve Idari Bilimler Fakültesi Dergisi, 2, 65-82.

Kocamanlar, E. (2009). Ambalaj ve fonksiyonları. Ambalaj Bülteni, Eylül-Ekim , 34-38.

Kotler, P., \& Keller, K. L. (2012). Marketing management (14. Baskı). Pearson Education Limited.

Koyuncu, K. (2007). Marka ve ambalajın tüketici satın alma davranışları üzerine etkisi. Niğde Üniversitesi Sosyal Bilimler Enstitüsü, Yüksek Lisans Tezi, Niğde.

Köklü, N. (1995). Tutumların ölçülmesi ve Likert tipi ölçeklerde kullanılan seçenekler. Ankara Üniversitesi Eğitim Bilimleri Fakültesi Dergisi, 28(2), 81-93.

Odabaşı, Y., \& Barış, G. (2003). Tüketici davranışı (2.Baskı). stanbul: MediaCat Akademi.

Örücü, E., \& Tavşancı, S. (2011). Gıda ürünlerinde tüketicinin satın alma eğilimini etkileyen faktörler ve ambalajlama. Sosyal ve Beşeri Bilimler Araştırmaları Dergisi, 1(3), 109-122.

Özçiçek-Dölekoğlu, C. (2002). Tüketicilerin işlenmiş gıda ürünlerinde kalite tercihleri, sağlık riskine karşı tutumları ve besin bileşimi konusunda bilgi düzeyleri (Adana örneği). Çukurova Üniversitesi Fen Bilimleri Enstitüsü, Doktora Tezi, Adana.

Özdemir, A. (2010). Yönetim biliminde ileri araştırma yöntemleri ve uygulamalar (2. Baskı). İstanbul: Beta Yayınevi.

Özdemir, T. (2005). Tasarımda renk seçimini etkileyen faktörler. Çukurova Üniversitesi Sosyal Bilimler Enstitüsü Dergisi, 14(2), 391-402.

Penpece, D. (2006). Tüketici davranışlarını belirleyen etmenler: Kültürün tüketici davranışları üzerindeki etkisi. Kahramanmaraş Sütçü İmam Üniversitesi Sosyal Bilimler Enstitüsü, Yüksek Lisans Tezi, Kahramanmaraş.

Pivato, S., Misani, N., \& Tencati, A. (2008). The impact of corporate social responsibility on consumer trust: The case of organic food. Business Ethics: A European Review, 17(1), 3-12.

Rundh, B. (2005). The multi-faceted dimension of packaging: Marketing logistic or marketing tool? British Food Journal, 107(9), 670-684.

Saraçlı, S., \& Şıklar, E. (2005). Bireysel emeklilik şirketlerinin tercihinde etkili olan faktörlerin konjoint analizi ile incelenmesi. Anadolu Üniversitesi Sosyal Bilimler Dergisi, 5(2), 1-12.

Sönmez, H. (2006). Müşteri tercihleri için konjoint analizi uygulaması: Ev bilgisayarı nasıl seçilir. Sosyal Bilimler Dergisi, 2, 185-196.

Sünnetçioğlu, ì. (2006). Kozmetik sektöründe ambalajlamanın rolü ve önemi: parfüm üzerine geliştirilmiş bir örnek uygulama. Dokuz Eylül Üniversitesi Sosyal Bilimler Enstitüsü, Yüksek Lisans Tezi, İzmir.

Sütütemiz, N., Çiftyıldız, S. S., \& Konuk, F. A. (2009). Paketlenmiş süt için ambalaj özelliklerinin algılanan önemi ve satın alma davranışına etkisi: İstanbul ili örneği. Akademik Gıda, 7(6), 18-28.

Şen, H., \& Çemrek, F. (2004). Konjoint analizi ve özel dersane tercihine yönelik bir uygulama. Osmangazi Üniversitesi Sosyal Bilimler Dergisi, 5(2), 105-120. 
Ürün Tercihlerini Etkileyen Ambalaj Tasarım Faktörlerinin Kısmi Yarar Konjoint Analizi İle Belirlenmesi: Organik Sabun Ürünü Üzerine Bir Çalıșma

Tuncalı, T. (2007). Seçime dayalı konjoint analizi yöntemi ile GSM servis sağlayıcı seçiminde etkili olan faktörlerin araştırılması ve uygulama. Marmara Üniversitesi Sosyal Bilimler Enstitüsü, Yüksek Lisans Tezi, İstanbul.

Turanlı, M., Cengiz, D. T., \& Işık, M. (2013). Konjoint analizi ile gazete tercihlerini etkileyen faktörlerin belirlenmesi. istanbul Üniversitesi iktisat Fakültesi Ekonometri ve İstatistik Dergisi, 19, 1-26. 